\title{
Comparison of spatio-temporal evolution of extreme precipitation events between two high-resolution models in a northern Europe case study
}

Thomassen, Emma Dybro; Kendon, Elisabeth; Sørup, Hjalte Jomo Danielsen; Chan, Steven; Langen, Peter L.; Christensen, Ole B.; Arnbjerg-Nielsen, Karsten

Link to article, DOI:

10.5194/egusphere-egu2020-18467

Publication date:

2020

Document Version

Publisher's PDF, also known as Version of record

Link back to DTU Orbit

Citation (APA):

Thomassen, E. D., Kendon, E., Sørup, H. J. D., Chan, S., Langen, P. L., Christensen, O. B., \& Arnbjerg-Nielsen, K. (2020). Comparison of spatio-temporal evolution of extreme precipitation events between two high-resolution models in a northern Europe case study. Abstract from EGU General Assembly 2020.

https://doi.org/10.5194/egusphere-egu2020-18467

\section{General rights}

Copyright and moral rights for the publications made accessible in the public portal are retained by the authors and/or other copyright owners and it is a condition of accessing publications that users recognise and abide by the legal requirements associated with these rights.

- Users may download and print one copy of any publication from the public portal for the purpose of private study or research.

- You may not further distribute the material or use it for any profit-making activity or commercial gain

- You may freely distribute the URL identifying the publication in the public portal 


\section{Comparison of spatio-temporal evolution of extreme precipitation events between two high-resolution models in a northern Europe case study}

Emma D. Thomassen ${ }^{1,2,3}$, Elisabeth Kendon ${ }^{4}$, Hjalte J. D. Sørup ${ }^{1}$, Steven Chan ${ }^{3,5}$, Peter L. Langen ${ }^{2}$, Ole B. Christensen ${ }^{2}$, and Karsten Arnbjerg-Nielsen ${ }^{1}$

${ }^{1}$ Department of Environmental Engineering, Technical University of Denmark, Denmark (edth@env.dtu.dk)

${ }^{2}$ Danish Meteorological Institute, Denmark

${ }^{3}$ Visiting scientist at Met Office Hadley Centre, UK

${ }^{4}$ Met Office Hadley Centre, UK

${ }^{5}$ Newcastle University, UK

Convection Permitting Models (CPM) are believed to improve the representation of precipitation extremes at sub-daily scale compared to coarser spatial scale Regional Climate Models (RCM). This study seeks to compare how the spatio-temporal characteristics of precipitation extremes differ between a $2.2 \mathrm{~km}$ CPM and a $12 \mathrm{~km}$ RCM from the UK Met Office with a pan-European domain.

Storm data have been re-gridded to a common $12 \mathrm{~km}$ grid and all events in the period from 1999-2008 are tracked with the DYMECS tracking algorithm. A peak-over-threshold method is used to sample extreme events within a northern European case area. Maximum intensity and maximum area of extremes are sampled based on the maximum intensity and maximum size reached within their lifetime. Evolution in size and intensity, track patterns, and seasonal occurrence of extreme events are compared between the two models.

For the top 1000 extreme events with the highest maximum intensities, the two models show disagreement in movement direction and spatial and temporal occurrence. While the CPM data are dominated by south-north moving events occurring in summer over central Europe, the RCM data are dominated by west-east moving events occurring over UK and more uniformly distribution over the year. The CPM and RCM however show good agreement in these variables for extreme events instead selected based on largest spatial area. A comparison with the COSMO REA6 reanalysis model continuously nudged towards observations indicates a similar spatial and seasonal distribution of extreme events sampled by maximum intensity as in the CPM. Analysis of the evolution of storms over their lifetime shows on average higher intensities and spatial areas of the most intense storms in the RCM data compared to the most intense storms in the CPM data. Sampling of maximum intensity extreme events in each of the four seasons show larger disagreement between the two models in the evolution in intensity and size in autumn (SON) and winter (DJF) than in spring (MAM) and summer (JJA). 